\title{
Foreword: Jane H. M. Taylor
}

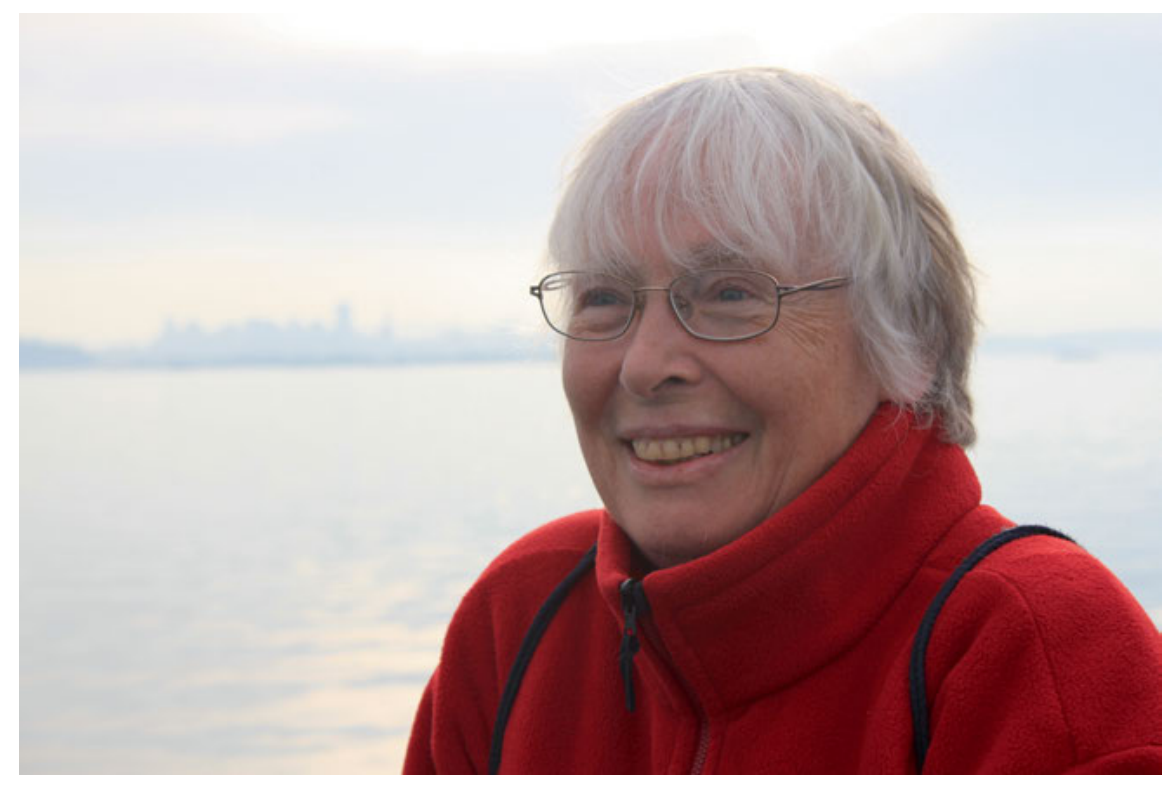

Fig. 1: Jane H. M. Taylor (photo: Jessica Taylor)

Jane's life has been fuelled by a love of adventure.

Where could this have come from? Perhaps from her love of the mountains, which has seen her crest impressive peaks in multiple continents over the years? Perhaps from her potholing, dare-devil father, who capitalized on her size as a small child to send her deep into newly discovered caves (having just blown them up using the dynamite kept in a drawer at home!)? I attribute Jane's love of adventure to an unquenchable curiosity and an enviable trust in the universe, which have seen her continually take on challenges throughout her eight decades.

Jane was born in West London, in 1941. Her parents, Jack and Muriel Burnett, met as undergraduate scholars and communists in Oxford in the 1930s. Jack was a civil engineer who worked on RADAR during World War Two. Muriel taught English and linguistics. 
A London war baby, Jane's first memory was of an air raid siren. Before long, she was evacuated from London to her paternal grandmother's house in Norham Gardens in Oxford. In 1953, the Burnetts moved from London to Hexham in Northumberland, a very happy move for Jane. Jack was a keen mountaineer and took his family away at weekends and for longer holidays in his badly converted military ambulance. Jane was enthusiastic - unlike her sister and mother - and she and her father walked extensively together in Northumberland and in the Highlands, with Jane often trailing several mountain tops behind him.

At school, Jane excelled in literature and languages and she longed to visit France. In 1957, she jumped at the offer of a French exchange. So it came about that Jane's first trip on her own was made to France aged 15, unaccompanied. The journey involved multiple trains, a ferry crossing and treks between stations in London and Paris. Her arrival in Macon, exhausted, at her French family's house, was made all the more memorable by the "lemonade" with which they greeted her. It was only when she fell up the stairs later that evening, that she realised that she'd been drinking her first glasses of Champagne. Jane was hooked.

Jane won a scholarship to her mother's college, St Hilda's, Oxford, to read French. But before going up, she embarked upon another French sojourn, this time as an au pair to the seven unruly sons of a family living just outside Paris. All previous au pairs had left within weeks; Jane stayed the full contracted six months, keeping order (just about) and building strong bonds. After she left, all the boys were sent to a military boarding school.

Going up to Oxford in 1960, Jane revelled in others' encouragement and belief in her. She joined the Oxford University Mountaineering Club (OUMC) and quickly became part of a strong community that endures today. She met Colin Taylor, a Physics doctoral student, and passionate mountaineer, and in him, she had found another adventurous spirit. They married in 1964, a year into Jane's DPhil, after a term spent in Paris. Still working on her DPhil, Jane was appointed to the French Department at Manchester University in 1966, while Colin took a job nearby at the Risley Atomic Energy Authority. The young couple enjoyed many mountain adventures together - in the Dolomites, Alps, Scotland. They were both still independently spirited, Jane continuing her intellectual life in Paris, Colin travelling to the Himalayas.

Just after I was born in 1974, Colin was tragically killed in an accident in the mountains above Zermatt in Switzerland. Of course, this hit Jane very hard, as did her mother's death just a few years later, and times were tough for our little family. Despite this, they were still full of adventure: a sabbatical to Paris in the early 80s, skiing and mountaineering trips and annual visits to the Vercors. 
Jane's friends in Manchester, in the French Department and beyond, provided great support for her during this time.

Jane met and married John Gurd in 1987, a professor of Computer Science at Manchester University. Her life - and mine - was transformed and as a new family, we travelled widely, hut to hutting in Austria, interrailing around Europe, and climbing Half Dome in Yosemite on a trip to California. Jane and John enjoyed two sabbaticals in Boston, Jane at Harvard and John at MIT.

In 1990, Jane secured a fellowship at St Hilda's and moved to Oxford for a decade. Her first tutorial lasted over two hours - and she was thrilled. It was here that Jane's love of teaching and ability to connect with students really came into its own. Throughout her career, Jane has always been passionate about scholarship, but equally committed to her students. She champions them, supports them to find their voices, and encourages them to reach higher and delights in their achievements. This diaspora is now extensive, global, and extremely successful!

With a flourish, Jane rolled the dice again in 2001. She and John moved their main home from Manchester to the Cumbrian hills and she returned to the north east for her final post. Her dual role as Principal of Collingwood College and Professor of French at Durham University was perhaps the most fulfilling of her professional life. Jane was able to combine her leadership experience at scale alongside her teaching and increasingly prolific publishing schedule - a winning formula. Officially retiring in 2009, Jane has of course done nothing of the sort, and publishes widely, chairs committees, speaks at conferences and stays "in the business".

The adventuring has continued, too, with trips to the wilderness of the Wind Rivers in Wyoming, another sabbatical - in California this time - and trekking in the Himalayas. In 2006, Jane and I went to Africa together - to Kenya and Tanzania. We had a wonderful time walking and camping in the Crater Highlands, a volcanic region of Tanzania but I suspect if asked what she remembers most about that trip, Jane would say the little school we visited in the middle of nowhere and the pupils to whom she managed to send school books and equipment as soon as she returned to England.

Jane remains an inspiration to so many of us in her adventuring, her teaching and in her life - and long may it continue. It is entirely fitting that she should be the honoree of this Festschrift. To those organizing it, thank you for recognizing the contribution Jane has made not only to medieval French scholarship but also to the lives of so many of her students throughout her professional life. 
XVI - Jessica Taylor

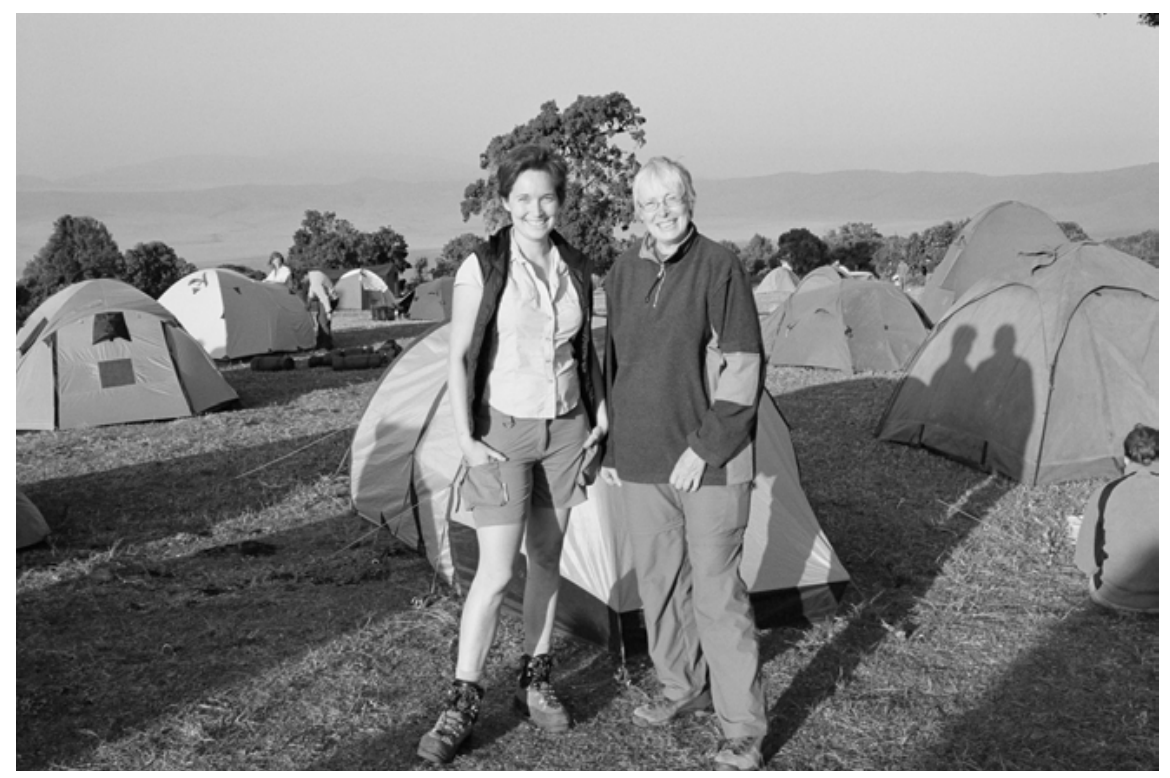

Fig. 2: Jessica Taylor and Jane H. M. Taylor in Africa (photo: Jessica Taylor) 